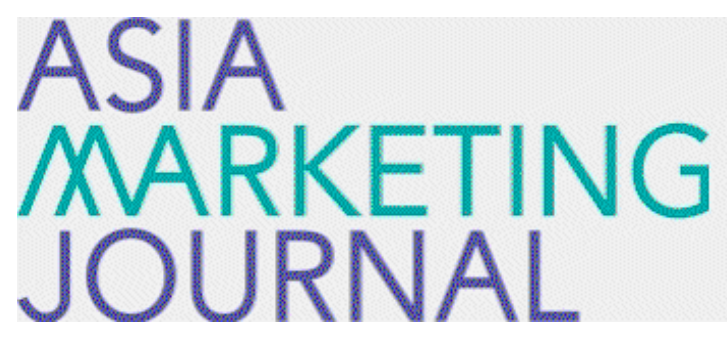

ASIA MARKETING JOURNAL

Volume 7 | Issue 3

Article 8

$10-27-2005$

\title{
대한항공의 인터넷 마케팅 전략
}

Jae II Kim

Jin Gyo Kim

Dong Hoon Kim

Follow this and additional works at: https://amj.kma.re.kr/journal

Part of the Marketing Commons

\section{Recommended Citation}

Kim, Jae Il; Kim, Jin Gyo; and Kim, Dong Hoon (2005) "대한항공의 인터 넷 마케팅 전략," Asia Marketing Journal: Vol. 7 : Iss. 3 , Article 8.

Available at: https://doi.org/10.53728/2765-6500.1155

This Article is brought to you for free and open access by Asia Marketing Journal. It has been accepted for inclusion in Asia Marketing Journal by an authorized editor of Asia Marketing Journal. 


\section{대한항공의 인터넷 마케팅 전략*}

\section{Korean Air: An Internet Marketing Case*}

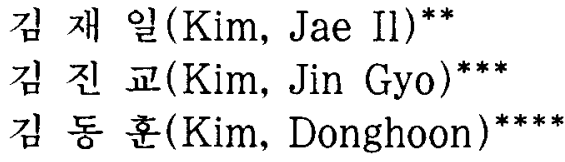

본 논문은 성공적으로 인터넷을 전략적으로 활용하고 있는 대한항공의 인터넷 마케팅 전략을 소개 한다. 구체적으로 대한항공의 인터넷 마케팅에 대한 비전, 미션, 그리고 구체적 전략을 소개하고, 그 효과 및 성과를 논의한다.

핵심개넘: 인터넷 마케팅, 전자상거래, E-CRM

\section{I. 서 론}

전세계 항공산업은 1990년 이후 10 여 년간 연평균 $8 \%$ 에 달하는 높은 성장을 유지해 왔 다. 21 세기에 들어서면서 전세계 항공기의 숫 자는 1980년에 비해 3 배 이상 증가하였으며. 이와 같은 고성장은 유가의 안정과 세계 경제 의 호전에 힘입어 향후 계속될 것으로 기대된 다. 그러나 이와 같은 고성장에도 불구하고 항 공사들의 영업수익률은 다른 산업들과 비교하 여 볼 때 전통적으로 낮은 까닭에 항공사간
경쟁강도가 상대적으로 매우 높은 것이 사실 이다.

항공산업에 있어서 장기적 생존과 경쟁적 우 위를 확보하기 위한 결정적 두 요인은 다음과 같다. 첫째, 설비, 항공기, 인력 측면에서의 운 영비용의 감소를 통한 영업수익의 개선이다. 예 를 들어 많은 항공사들이 550 명 이상의 승객을 수송할 수 있는 대형항공기를 다투어 도입하는 까닭도, 기존의 400 여명을 수송하는 항공기의 경우 탑승객 수를 기준으로 한 항공기당 손익 분기점이 290 여명( $72.5 \%$ 탑승률)인 데 반해서. 550 명 이상을 수송하는 대형항공기의 경우 320 명

* 사례개발에 도움을 준 대한항공 관계자 여러분과 서울대학교 석사과정 이기연 학생에게 감사를 드립니다.

** 서울대학교 경영대학 교수(jaekim@snu.ac.kr)

*** 서울대학교 경영대학 조교수(jingkim@snu.ac.kr), 교신저자

**** 연세대학교 경영대학 교수(dhkim@yonsei,ac.kr) 
(58.18\% 탑승률)이기 때문이다(Global Aerospace 2000). 둘째, 고객 서비스 수준의 제고이다. 항 공사들 간에 항공기 등 물리적 설비 측면에서 의 차이가 미미하거나 매우 적은 까닭에, 서비 스 수준의 차별화를 통한 경쟁우위의 확보가 매우 중요하다.

20세기 말 인터넷의 급속한 보급화에 부흥하 여 외국의 여러 항공사들이 급속도로 인터넷을 도입한 것은 주지의 사실이다. 이는 인터넷의 도입을 통하여 다음과 같은 여러 전략적 효과 를 달성하는 것이 가능하였기 때문이다.

첫째, 운영비용의 감소: 인터넷을 판매와 운 영에 도입함으로써 항공사들은 발권, 유통 채널 상의 운영비용을 감소시킬 수 있다. 기존에 항 공사들이 수행한 서비스 기능들을 고객에게 전 가함으로써 상당 부분에 달하는 고정비용 또한 줄일 수 있다.

둘째, 고객서비스 수준의 제고: 인터넷을 통 하여 항공상품에 대한 정보를 광범위하고 신속 하게 고객들에게 제공하고, 고객들로 하여금 구 매를 직접 할 수 있게 하고, 나아가 고객들과 직접 접촉을 함으로써, 고객들 각각을 위한 개 별 서비스(personalized service)의 제공을 통해 서비스 수준의 향상이 가능하다. 특히 주어진 항공사에 대하여 충성도가 높거나 반복구매율 이 높은 고객들을 보다 효율적으로 발굴한 후, 보다 나은 수준의 차별화된 서비스를 제공함으 로써 수익의 향상을 꾀할 수 있다.

셋째, 판매량의 증가: 24 시간 전세계 어디에 서든 항공상품을 쉽고 빠르게 구입하도록 하고, 나아가 각 항공기의 탑승률을 높이기 위한 여 러 방법들(예: overbooking)을 보다 탄력적으 로 운영함으로써, 전반적인 판매량의 증가를 꾀
할 수 있다. 이와 같은 판매량의 증가는 운영비 용의 감소와 결부됨으로써 항공사의 가격경쟁 력을 개선시킬 수 있다.

넷째, 유통구조의 혁신: 인터넷 도입 이전에 는 여행사를 통하여 항공권의 판매가 이루어졌 는테, 이는 높은 수준의 수수료의 지불을 발생 시켰을 뿐만 아니라. 여행사 등 중간 유통 채널 의 서비스 수준에 대한 통제가 용이하지 않았 다는 문제가 있었다. 인터넷의 등장으로 인해 중간 유통 채널을 생략하고 직접 고객과 거래 하는 것이 가능하게 되었는데, 이는 고객서비스 수준의 개선과 비용감소의 효과를 동시에 가져 올 수 있다.

대한항공 또한 위와 같은 인터넷의 전략적 효 과를 일찍이 간파하고 인터넷을 전략적으로 활 용해 왔다. 본 논문에서는 대한항공이 현재 어 떻게 인터넷을 전략적으로 활용하고 있는 지를 살펴보고자 한다.

\section{II. 대한항공 인터넷 마케팅: 비전 및 미션}

\section{1 비전}

인터넷 마케팅에 대한 대한항공의 비전은 "Off-line의 모든 서비스와 판매는 On-line에서 도 가능하다"라는 문구로 요약할 수 있다(《그 림 2-1〉 참조). 구체적으로 On-line 서비스 및 판매체제 구축을 위해 'Middleman의 전문지식 을 고객의 것으로'. '고객의 욕구 파악 및 Function의 개발', '선별적 정보에서 개방적 정보 
〈그림 2-1〉 대한항공의 인터넷 마케팅에 대한 비전 및 미션

대한항공 Offline의 모든 서비스와 판매는

Online에서도 가능하다
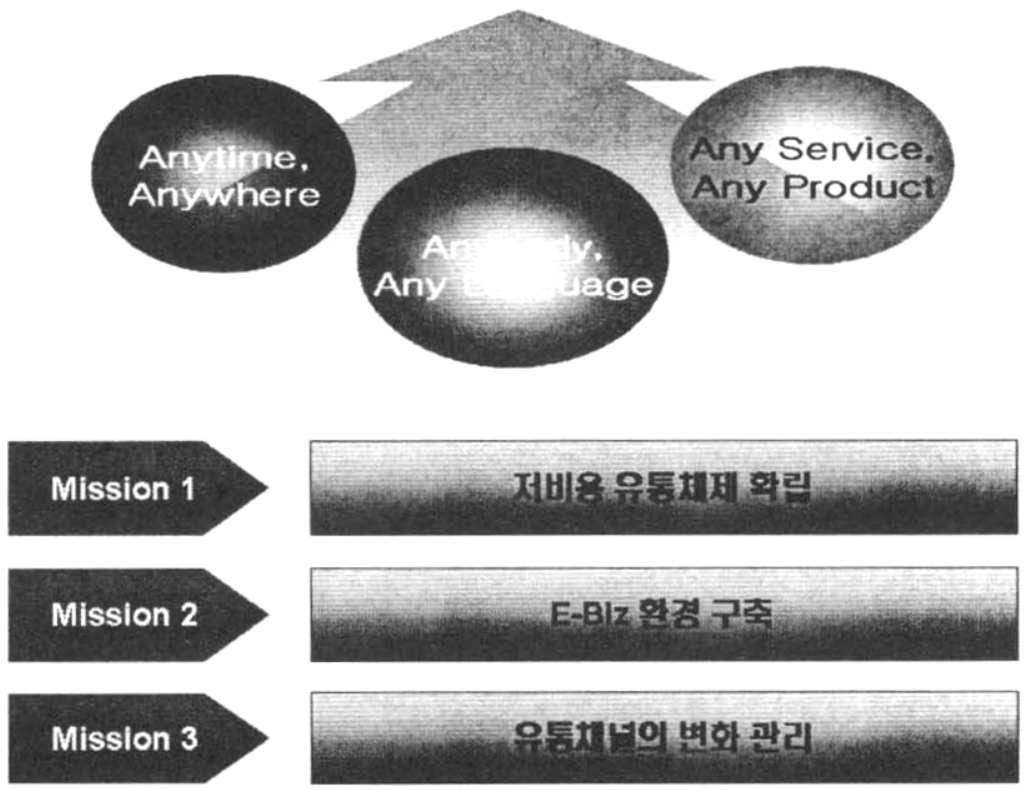

제공으로', 'IT 발전 및 환경변화에 따른 기민한 적응'이라는 목표 아래 기존의 Off-line 서비스를 On-line 환경 하에서 더욱 편리하게 제공하고 자 하였다.

\section{2 미션}

인터넷 마케팅에 대한 비전을 실현하기 위해 대한항공은 다음과 같은 세 미션을 수립하였다.

첫째, 저비용 유통체제의 구축이다. 전통적으 로 항공업계의 유통구조는 상품설계와 마케팅 은 항공사가 담당하고, 항공권과 여행 패키지의 판매는 내부 및 외부 여행대리점이 담당하는 간접판매의 형태였다. 그러나 이와 같은 간접판 매의 유통체계는 여행대리점 관리를 위한 판매
조직 운영의 필요성, 그리고 여행사 커미션 제 공으로 인한 비용의 증가라는 단점을 안고 있 었다. 이와 같은 고비용 유통체제를 저비용 유 통체제로 전환시키기 위해서 대한항공은 인터 넷을 통해 항공권 및 여행 패키지를 직접 판매 하고자 하였다. 그 결과로, 대한항공은 대리점 의 커미션 비용을 감소시키고, 고객으로 하여금 직접 예약과 발권업무를 수행함으로써 기존의 예약/발권 시설, 판매 시설, 인력, 그리고 판촉 활동 등에 소요되는 비용을 절감할 수 있을 것 으로 기대하였다.

둘째, 가치체인의 변화이다. 인터넷은 고객과 의 직접채널인 까닭에 양방향 커뮤니케이션이 가능하다. 인터넷을 통하여 고객의 욕구 등에 대한 정보를 직접 획득함으로써. 기존의 가치체 
인을 변화시키는 것이 가능하다(〈그림 2-2〉 참 조). 어떤 고객이 언제 무엇을 구매하며, 어떤 정보를 원하는가 등에 관한 중요정보가 대한항 공에 실시간으로 제공됨에 따라 대한항공은 고 객의 욕구를 보다 정확하게 이해할 수 있으며. 나아가 고객들과 직접적인 관계를 형성함으로 써 유통채널상 전통적으로 파워가 큰 중간채널 구성원들로부터 파워를 되찾아올 수 있게 될 것이고, 궁극적으로 중간유통업체들에 대한 협 상력의 제고를 통해 수익성의 향상을 꾀할 수 있을 것이다.

셋째, 미래에 요구되는 새로운 시장위치 정립 에 대한 준비이다. 대한항공은 여행산업에서 온 라인의 비중이 점차 확대되고 있는 유통채널 구조의 변화를 앞서 파악하고 주도적으로 변화 를 관리함으로써 시장위치의 재정립에 대비할 수 있다. 미국의 경우 여행산업에 있어서 인터 넷 판매 비중이 2000 년에 $54 \%$ 에 달하였다 (Center for Regional and Tourism Research 2003). 인터넷 강국이라 불리는 한국 역시 향후
여행산업에서 인터넷 판매의 비중이 계속적으 로 증가할 것으로 예상된다. 이와 같은 인터넷 판매의 증가에 따른 인터넷 마케팅의 활성화가 항공산업에 있어서 어떠한 지각변동을 궁극적 으로 가져올 지는 현재의 상황에서 예측하기는 어렵다. 그러나. 인터넷 마케팅의 초기단계는 단순한 항공권의 판매에 국한되겠지만, 경쟁 기업보다 먼저 인터넷 마케팅을 활성화함으로 써 대한항공은 향후 미래에 요구되는 시장위 치를 신속하게 재정립하는 것이 가능할 것이 다. 예를 들어 경쟁 - 규제 - 기술 등의 환경의 변화에 대응하여 단순하게 항공권 판매를 주업 으로 하는 항공권판매사(ticket vendor)로부터 항공여행도우미(air travel organizer), 여행총괄 제공사(total travel solution provider), 항공여행 쇼핑몰(air travel shopping mall) 등의 발전된 형태로의 변신을 꾀할 수 있을 것이다(〈그림 2-3) 참조).

〈그림 2-2〉 인터넷 마케팅을 통한 가치체인(value chain)의 변화

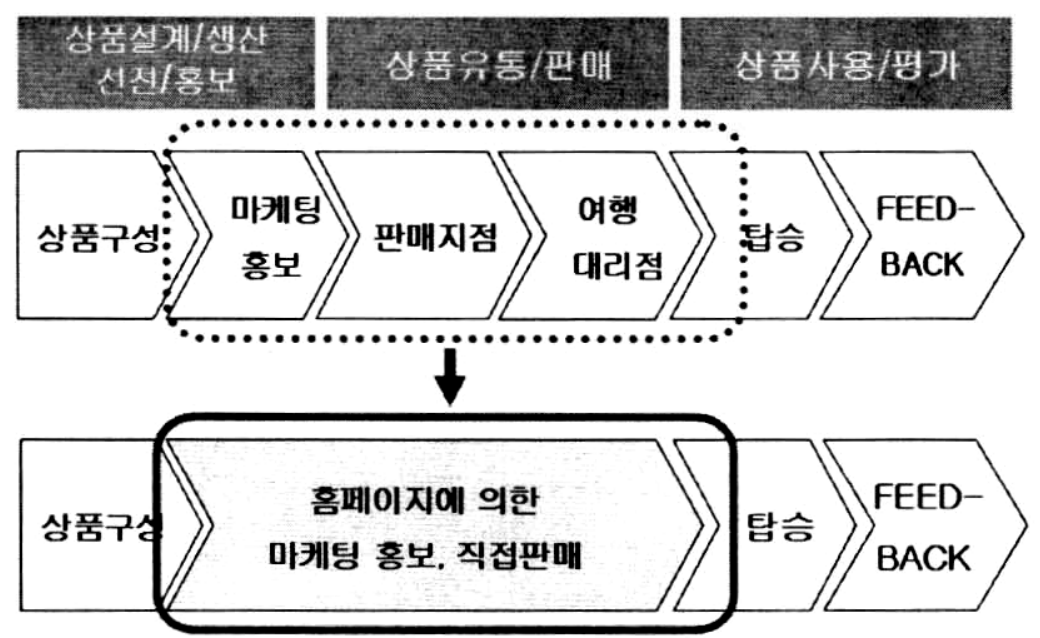


〈그림 2-3〉 홈페이지 내 의사소통과 통합의 정도에 따른 E-business 유형의 구분

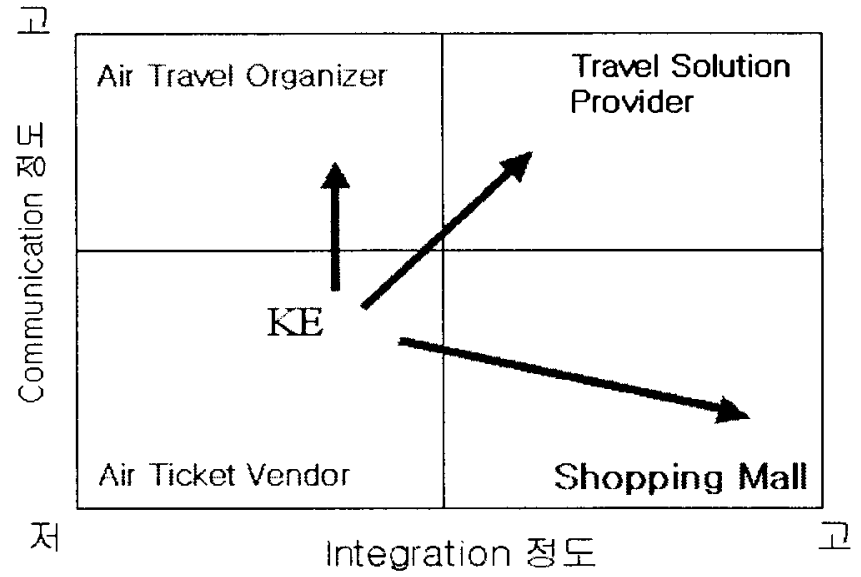

III. 대한항공의 인터넷 마케팅 전략 사이트의 컨셉을 단계별로 수립하여 웹사이트 의 주요 구성요소인 콘텐츠, 그래픽 디자인, 구 조 및 네비게이션을 상호 유기적으로 결합함으

3.1 웹 사이트 운영 전략 로써 시너지 효과를 극대화하고자 하였다.

대한항공 최초의 홈페이지는 1997년 1월에 운 대한항공은 〈그림 3-1〉에서 볼 수 있듯이 웹 영이 시작된 영문 홈페이지(www.koreanair.com)

〈그림 3-1〉 대한항공 웹 사이트 발전단계 및 역할변화

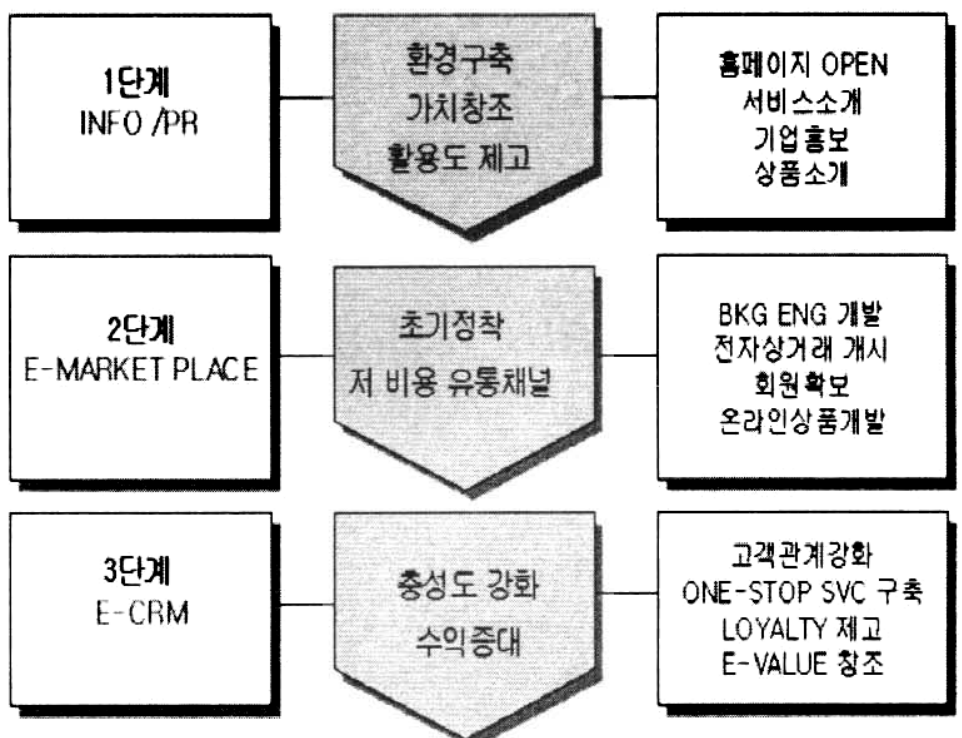


이었으며, 5 개월 후인 1997년 6월에 한글 홈페 이지 (www.koreanair.co.kr) 또한 개설되었다. 1 단계에 속하는 이 시기에는 웹 사이트 환경의 구축, 그리고 기업 및 상품 홍보가 주 목표였다. 2단계에서는 인터넷의 발달과 인터넷 사용자 의 기대수준의 상승에 발맞추어 웹 사이트를 저비용 유통채널로써 적극적으로 활용하기 위 해 $\mathrm{BKG}$ 엔진을 개발함으로써. 온라인회원의 확보, 온라인 상품의 개발, 그리고 전자상거래 의 구현을 추진하였다. 북미 지역에서는 1998년 4 월부터 온라인 판매를 시행하였고, 국내의 온 라인 판매는 국내선의 경우 1997년 10월에, 국 제선의 경우 1999년 3 월에 개시되었다.

2005년 현재 대한항공의 웹 사이트는 2단계에 서 3단계로 넘어가는 과도기 단계에 있다. 국내 홈페이지는 운항 스케줄의 조회. e-ticket의 예 매, 그리고 SKYPASS의 조회를 제공하며, 고 객 편의를 위하여 SMS 서비스, 출도착 시간조 회, 실시간 운항 정보 및 공항 기상 정보 또한
제공하고 있다. 뿐만 아니라 세계 각지로 떠나는 여행객들을 위하여 CMS(Contents Management System)을 활용하여 취항지에 대한 국가/도시 별 여행정보를 제공하고 있다. 덧붙여, 고객을 위한 열린 네트워크의 장으로써 여행관련 동호 회, 생생 여행후기 등의 커뮤니티도 운영되고 있다. FAQ 및 고객의 말씀 등의 코너를 통하 여 고객 지원 센터는 고객들의 문의·제언·불만 등을 수집-활용함으로써 고객서비스 수준의 제고를 위해 힘쓰고 있다. 이와 같은 활동을 통 하여 대한항공은 궁극적으로 E-CRM을 구현하 는 것을 그 목포로 하고 있다.

해외의 경우 현재 총 6 개 지역에서 5 개의 언어 로 7개의 웹 사이트를 운영하고 있다(〈그림 3-2〉 참조). 해외 사이트들도 국내 흠페이지와 유사하 게 예약, 여행가이드 SKYPASS 등의 서비스를 제공하고 있다. 2004년 6월 인터넷 회원의 데이터 베이스를 통합함으로써 1 개의 회원 아이디로 전 세계 어느 사이트로든 로그인이 가능하게 하였다.

〈그림 3-2〉 전세계 대한항공 웹사이트의 현황

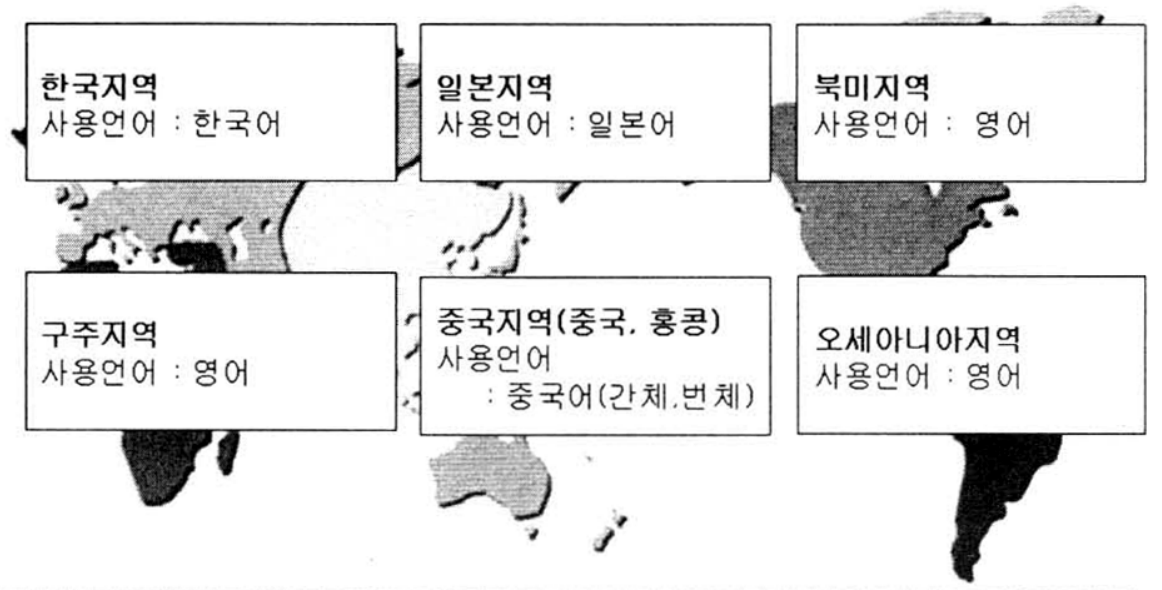

총 6 개 지역, 7 개 Website, 5 개 언어 운영 중 
〈그림 3-3〉 향후 범세계적 웹 사이트의 구축방향

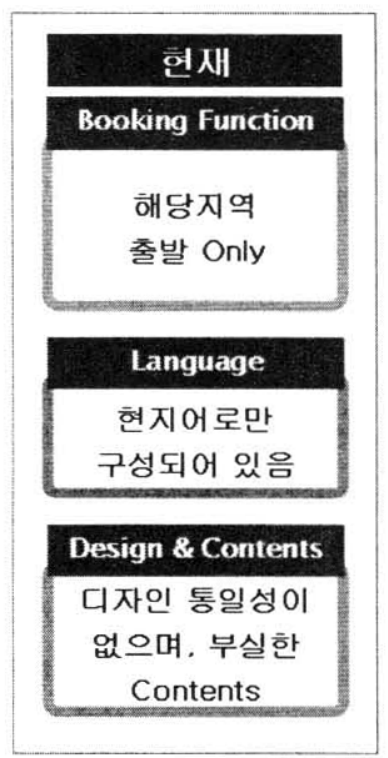

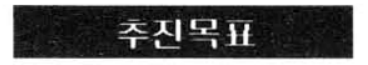

해당지역의

Local Site 수준예

머물러 있는 각 Site를

Global Site 수준으로

Upgrade

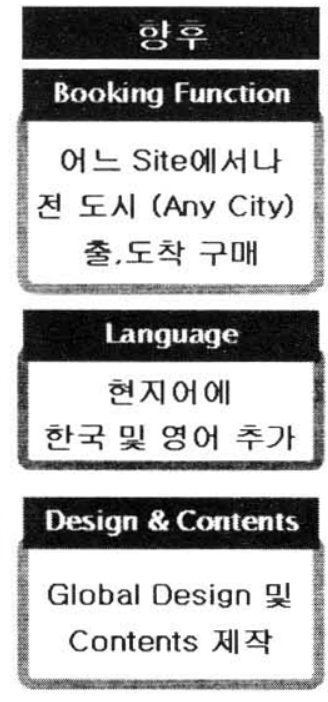

향후 추진목표는 대한항공을 대표하는 통일된 디자인으로, 언어의 불편이 없도록 하고, 전 지 역에 공통된 기본 콘텐츠를 제공하고, 세계 모 든 구간에 대한 구매가 어느 곳에서든 가능하 도록 하는 범세계적 웹사이트를 구축하는 것이 다(〈그림 3-3〉 참조). 구체적으로 6개 지역에 불어와 독어를 포함한 7 개 언어로 9 개 웹사이 트를 운영할 예정이다. 이와 같은 범세계적으로 통합된 웹사이트의 구축을 통해, 통일된 온라인 정책의 실행, 고객 편의성의 증대, 그리고 비용 감소 등의 효과를 기대하고 있다.

\section{2 인터넷 상품 전략}

인터넷 홈페이지를 판매 및 유통을 위한 새로 운 수단으로 활용함으로써. 고객에게 저비용과 편의성이라는 편익을 제공하여 궁극적으로 매 출의 증대를 꾀하였다. 뿐만 아니라 대한항공은
온라인에 적합한 상품을 지속적으로 개발함으 로써 상품 측면에 있어서 오프라인과의 차별화 역시 추구하였다.

대한항공의 인터넷 상품은 크게 항공권과 여 행상품으로 나뉘어진다(〈그림 3-4〉 참조). 먼 저, 인터넷을 통한 항공권의 판매는 유통채널의 축소를 통한 비용절감 효과를 기대할 수 있으 며. 고객에게 상품정보를 직접적으로 전달할 수 있다는 이점이 있다. 여행상품은 항공서비스의 보다 발전된 형태의 상품으로서 항공권이 호텔 등의 부가상품과 꾸러미로 묶여 판매되는 상품 이다. 전문 여행사가 전문성과 경헙 측면에서 우위를 점하기 때문에, 대한항공은 외부 여행사 (한진관광, 넥스투어 등)와의 제휴를 통하여 다 양한 여행상품을 고객의 욕구에 맞추어 개발하 고 있다. 
〈그림 3-4〉 대한항공의 인터넷 상품
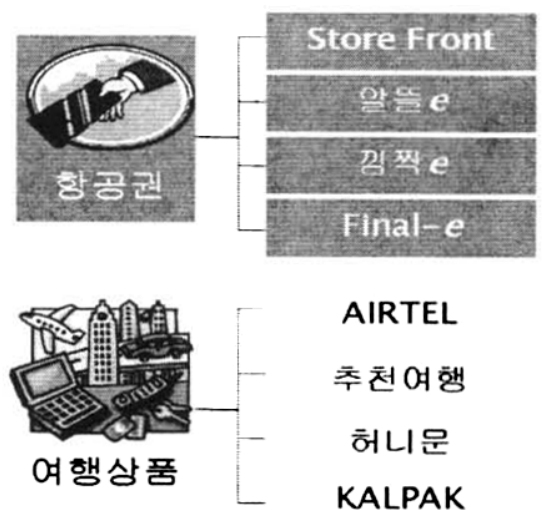

AIRTEL

추천여행

허니운

KALPAK
일반항공권

ADVANCE PURCHASE

SPOT SALE

LAST MINUTE SALE

항공권 + HOTEL

인기 PACKAGE 상픙

신혼여행상품

고급여행상품

\subsection{1 항공권 상품}

편의성과 가격을 기준으로 고객을 세분하여 다양한 형태의 항공권을 판매한다(〈그림 3-5〉 참조). Store Front 상품은 전통적인 일반항공권 을 지칭하며, 할인항공권 상품들로는 알뜰e, 깜 짝e, 그리고 Final-e 항공권이 있다.

(1) 일반항공권 판매: 항공권 구매 시 여행스 케줄과의 적합성과 운임규정 등의 편의성 을 중시하고 가격 변동에 덜 민감한 고충 성도고객을 대상으로 한 상품이다. 이는 편의성을 강조하고, 안정적인 가격 및 좌 석의 운영을 통해서 지속적인 재구매를 유도하는 데 그 초점이 있다.

(2) 알뜰e: 편의성보다는 가격에 민감한 저가 항공권 선호 고객층이 주표적이다. 이들 고객층은 미리 항공권을 구매하고 그에 맞추어 여행일정을 흔히 조정한다. 이 고 객들을 위해 다양한 노선들에 대하여 한 정된 숫자의 좌석을 오프라인에 비해서 크게 할인된 가격으로 제한적 운임조건을

더해서 실제 탑승일보다 상당 기일 앞서 서 판매하는 항공권이다. 이는 경쟁항공사 및 오프라인의 수요를 온라인으로 전환하 거나, 경쟁이 심하거나 매출이 부진한 노 선에 대한 매출을 증가시키는 데 그 목적 이 있다.

(3) 깜짝e: 예측이 불가능한 비정기적인 저가 의 할인항공권이다. 이는 고객들로 하여금 홈페이지의 반복적 방문을 유도함으로써 정가항공권의 판매를 증대시키는 데 주 목적이 있다. 이외에도 신규노선 또는 부 진한 노선에 대한 공격적인 가격운영으로 경쟁사의 항공수요를 대한항공으로 전환 시키거나 노선에 대한 인지도의 제고를 겨낭하여 판매된다.

(4) Final-e: 출발이 임박한 노선들 중 판매율 이 $70 \%$ 이하인 노선 편에 대해 마일리지 비제공 등 고객에 불리한 계약조건 하에서 퐈격적인 가격으로 판매하는 last minute 항공권으로서. 가격에 민감하고 충성도가 낮은 고객을 겨낭한다. 이는 일종의 loss leader로서 활용되며 고객을 유인하고 홈 


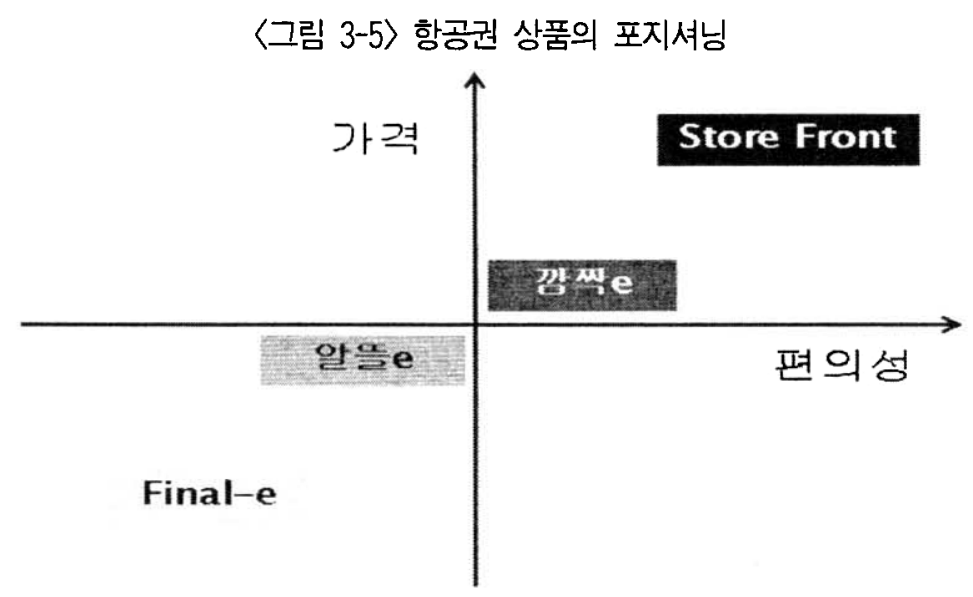

페이지에 대한 관심 진작을 위한 마케팅 도구로써 활용된다.

\section{2 .2 여행상품}

현재는 대한항공의 사업영역이 항공 서비스에 만 국한되어 있기 때문에, 여행상품에 대한 전 문성이 높은 외부 여행사와의 제휴를 통해서 고객에게 보다 다양한 여행상품을 제공하고자 노력을 집중하고 있다. 여행상품은 고객의 여행 스타일에 따라 $\mathrm{KAL}$ 에어텔, 추천여행, 허니문 패키지여행, KALPAK 등 네 가지 유형으로 구성되어 있다.

(1) $\mathrm{KAL}$ 에어텔: 항공권과 호텔만을 연계해 주는 상쭘으로 중소기업들의 업무용 수요 및 자유로운 개별여행을 선호하는 고객이 주 대상이다. 여행상품 중 가장 높은 판매 비중을 차지하며 향후 성장잠재력이 큰 상품이다. 판매를 위해 공격적으로 가격을 운영하고, 다양한 부가혜택을 제공하고. 경쟁력 있는 호텔의 유치에 힘을 쓰고, 예
약 시스템을 자동화하고, 나아가 고객 응 대 서비스를 향상시키고자 힘쓰고 있다.

(2) 추천여행: 대한항공에 대한 충성도가 높고 여행 목적에 적합한 상품을 직접 선택하는 반복 여행자를 위한 고품격 여행 상품이 다. 이 상품에는 특 1 급 이상의 호텔과 식 사를 제공하고 옵션여행이 포함되어 있으 며 일반 패키지 가격으로 여유롭고 알찬 일정을 보낼 수 있도록 한다.

(3) 허니문 패키지여행: 고품격 허니문 여행 상품으로서 계절적 상품 성격이 강하다. 차 별화된 상품 개발 및 프로모션을 통해 수 요를 증가시키고 있다. 예를 들어 고품격 상품 및 보는 여행, 즐기는 여행 등의 테마 성 리조트 상품을 개발하여 차별화를 꾀하 고 있으며, 결혼 연령층을 대상으로 이메일 을 통한 프로모션 마케팅을 펼치고 있다.

(4) KALPAK: 고품격 패키지여행을 추구하 는 중산층을 대상으로 한 일반 패키지와 는 차별화된 명품 여행상품이다. 상대적으 로 고가이나 흭일화된 관광 일정을 지양 하고 소수 인원을 위한 차별화된 일정 및 
서비스를 제공함으로써 고객 만족의 극대 화를 꾀하고 있다.

\subsection{3 항공권 및 여행상품 판매실적}

대한항공은 앞 절에서 설명한 항공권 및 여행 상품의 상품전략을 통해서 2004년도에 국제선 의 경우 450 억 원, 국내선의 경우 1,233 억 원의 매출을 달성하는 성과를 거두었다. 2004년 국제 선 판매실적은 2002 년의 170 억 원의 매출에 비
해 2.5배 이상 성장한 수치이다.

〈표 3-1〉에서 볼 수 있듯이, 일반 항공권 판 매 상품인 Store Front 항공권의 판매액은 271 억 원으로 $60.2 \%$ 의 높은 판매 비중을 차지하고 있 으며, 그 다음으로 알뜰e(21.1\%), 에어텔 $(8.5 \%)$, 깜짝e $(5.3 \%)$ 순으로 판매되었다.

위와 같은 대한항공의 인터넷 상품 판매는 지 속적으로 증가하는 추세를 보이고 있으며, 2008 년도에는 국제선 판매의 $15 \%$, 국내선 판매의 $80 \%$ 를 목표로 하고 있다(〈그림 3-6〉 참조).

〈표 3-1〉 2004년 국제선 항공권 및 여행상품 판매실적

(단위: 억원)

\begin{tabular}{|c|c|c|c|}
\hline \multicolumn{2}{|l|}{ 종 류 } & 2004년 & 비율 \\
\hline \multirow{4}{*}{ 항공권 } & Store Front & 271 & $60.2 \%$ \\
\cline { 2 - 4 } & 알뜰e & 95 & $21.1 \%$ \\
\cline { 2 - 4 } & 깜짝e & 24 & $5.3 \%$ \\
\cline { 2 - 4 } & Final-e & 10 & $2.2 \%$ \\
\hline \multirow{4}{*}{ 여행상품 } & 에어텔 & 38.2 & $8.5 \%$ \\
\cline { 2 - 4 } & 허니문 & 4.3 & $1.0 \%$ \\
\cline { 2 - 4 } & 추천여행 & 3.5 & $0.8 \%$ \\
\cline { 2 - 4 } & KAL PAK & 4 & $0.9 \%$ \\
\cline { 2 - 5 } & K & 450 & $100.0 \%$ \\
\hline
\end{tabular}

〈그림 3-6〉 향후 인터넷 상품판매의 목표
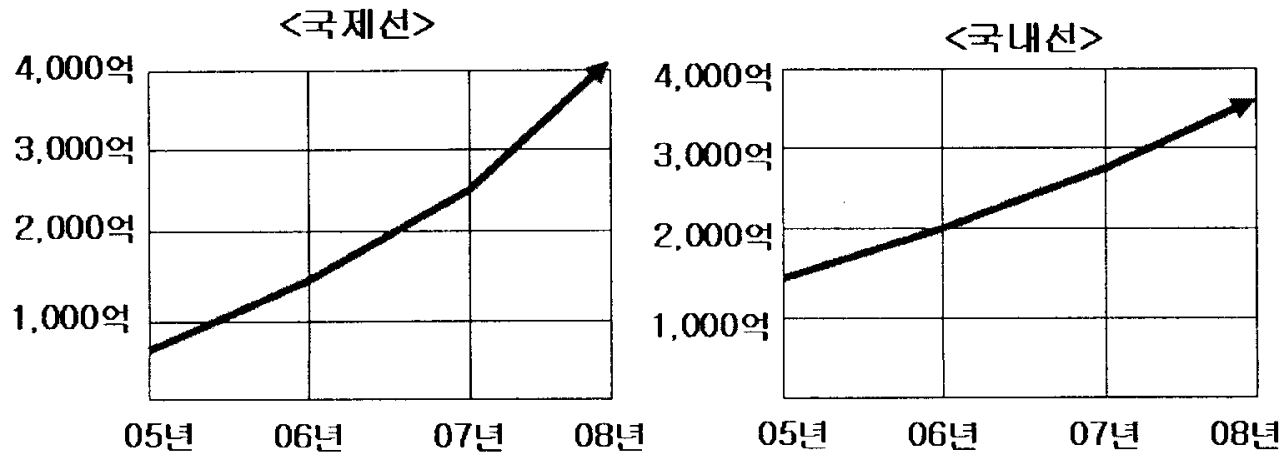


\section{3 인터넷 커뮤니케이션 전략}

전통적으로 커뮤니케이션은 대한항공으로부터 고객으로의 일방향으로만 이루어져 왔다. 그러 나 인터넷 마케팅을 통하여 대한항공과 고객간 의 커뮤니케이션은 일 대 일 또는 다수 대 다 수 등 다양한 형태 하에서 서로 정보를 주고받 는 쌍방향 커뮤니케이션의 구현이 가능하게 되 었다. 인터넷은 실시간의 쌍방향 커뮤니케이션 을 저렴하고 쉽게 구현할 뿐만 아니라, 광고, 판매촉진, 구전 등 다양한 형태의 방식으로 정 보의 확산 또한 촉진한다. 나아가 인터넷상 커 뮤니케이션은 고객 개개인에 대한 차별화된 관 리를 가능하게 한다.

인터넷의 등장으로 커뮤니케이션의 수단이 점차 다양해짐에 따라, 다양한 커뮤니케이션 형태를 통합적으로 관리할 필요성이 점차 증가 하였다. 이와 같은 통합적 인터넷 마케팅 커뮤 니케이션 활동(이두희 2003)을 위해 대한항공은 인터넷 마케팅의 주요 활동으로써 다음과 같은 다양한 커뮤니케이션 전략을 펼치고 있다.

\subsection{1 인터넷 커뮤니케이션 운영 전략}

대한항공은 인터넷 커뮤니케이션의 주요 전랴 으로서 크게 세 목표를 설정하였다. 첫째. 고객 과의 상호작용적 의사전달 통로의 구축을 통해 고객을 관리한다. 둘째, 시간 및 비용 절감을 통한 생산적 마케팅 활동을 지향한다. 셋째, 온 라인 커뮤니케이션 활동이 기존의 오프라인 커 뮤니케이션 수단들과 일관성을 유지하고 오프라 인 커뮤니케이션을 보조할 수 있도록 함으로써 통합적으로 커뮤니케이션 효과를 극대화한다.

\subsection{2 인터넷 커뮤니케이션 운영 현황}

위와 같은 인터넷 커뮤니케이션의 주요 운영 전랴을 토대로 대한항공은 인터넷 광고 및 이 메일을 주요 커뮤니케이션 수단으로 활용하고 있다.

인터넷 광고의 경우 대한항공 및 상품을 고객 에게 보다 적극적으로 알리기 위하여 주요 신 문 사이트 및 포탈 사이트에서 배너광고 및 키 워드 검색광고를 실시하고 있다.

인터넷 상에서 구현되는 쌍방향 의사소통 수 단인 이메일 또한 적극적으로 활용하고 있다. 이메일은 우편(direct mail)에 비해 두 가지 장 점이 있다. 첫째, 우편은 우송비가 들지만 이메 일은 우송비가 필요 없다. 둘째, 광고주의 웹 사이트에 간단히 접근하여 상세한 정보의 수집 과 상품 구입을 완결할 수 있는 등 직접반응 광고의 길을 열 수 있다(Strauss and Frost 1999). 대한항공은 이와 같은 이메일의 장점에 착안하 여 이를 적극적으로 활용함으로써 고객 관계 형성뿐만 아니라 시간 및 비용의 절감 효과를 얻고자 하였다.

이메일을 통한 커뮤니케이션 활동은 크게 3 가 지의 유형으로 분류된다. 먼저, 직접적 이메일 (direct e-mail)은 정기적인 뉴스레터의 발송 또는 신규노선 취항 및 이벤트 홍보를 위해 주 로 활용되고 있으며, 이는 향후 데이터베이스 마케팅의 주요 도구로 활용할 예정이다. 거래 이메일(transactional e-mail)은 고객이 인터넷 을 통해서 거래를 한 경우 제공되는. 거래와 관 련된 실시간 이메일이다. 이는 인터넷으로 항공 권 및 여행상품을 구매한 고객에게 회원정보, 예약정보, 구매정보 등의 정보를 실시간으로 이 
메일을 통하여 발송함으로써 고객의 편리성을 향상시키고자 한다. 마지막으로 설문조사 이메 일(survey e-mail)은 고객의 의견을 직접 수렴 하고 피드백 함으로써 고객 만족을 극대화시키 기 위한 이메일로서, 총 7,500 명이 가입하여 활 동하고 있는 4 개의 인터넷 커뮤니티('맛있는 여 행', '우린 그곳에 갔었다', '돈버는 쇼핑 이야기', '달리는 사람들')를 조사대상으로 활용하고 있 다. 또한 고객의 불만이나 제언 등을 접수하여 $\mathrm{FAQ}$ 및 개별응답 처리 등의 방법으로 고객에 게 피드백을 제공하고 있다.

\section{IV. 대한항공의 인터넷 마케팅의 성과}

\section{1 판매실적의 증가}

1997년 10 월에 시작된 대한항공의 국내 온라 인 판매는 2002 년에는 총 매출이 990 억 원에
달했고, 2003 년에는 $49 \%$ 성장하여 1.478 억 원 을 기록하였다. 2004 년의 경우 1,683 억 원으로 총 매출액은 증가했으나 성장률은 $13 \%$ 수준으 로 온라인 판매의 성장세가 다소 주춤하는 경 향을 보였다(〈그림 4-1〉 참고).

대한항공의 인터넷 상품 중 항공권만 살펴보 면, 2004년의 경우 판매 점유비를 살펴볼 때, 온라인을 통한 항공권의 판매는 국내선 총매출 액의 $20 \%$, 국제선 총매출액의 $2.7 \%$, 전체 총매 출액의 $7.4 \%$ 를 점하고 있다(〈그립 4-2〉, 〈그림 4-3〉 참조). 홈페이지를 통한 거래 현황의 경우 일일 예약건수는 10,000 건에 달하며, 일일 구매 건수는 5,000 건에 이르고, 일일 판매액은 국내 선 3 억 원, 국제선 1.5 억 원으로 총 4.5 억 원에 달한다.

\section{2 인터넷 회원의 증가}

1997년 6월에 국내 사이트를 오픈한 이래로 총 회원수는 지속적으로 증가하여 2004년 12월 현재 390 만 명에 달한다. 성별 비율을 살펴보면

〈그림 4-1〉 온라인 판매 실적

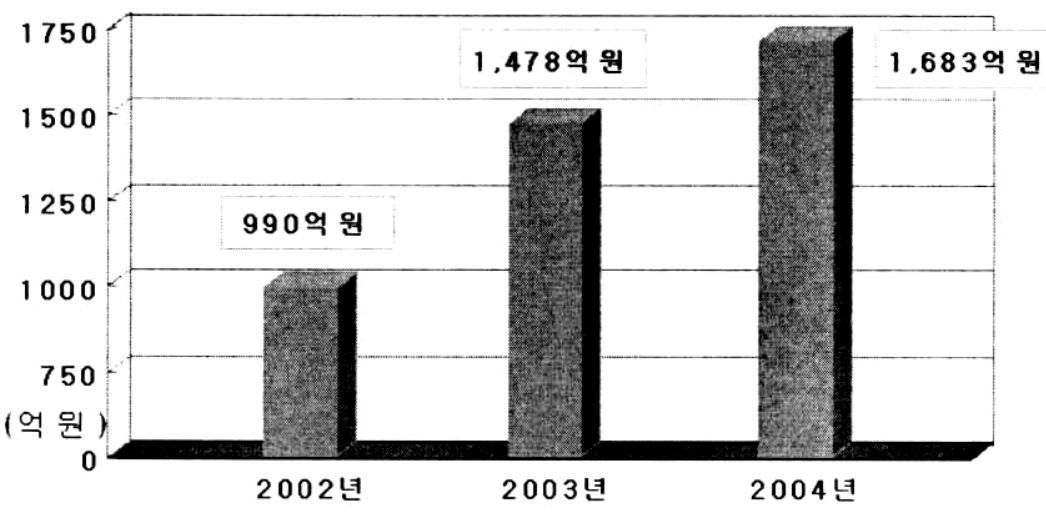


〈그림 4-2〉 국내선 항공권 판매실적

\begin{tabular}{|c|c|c|c|c|}
\hline 연 도 & 잍난 & 선저 딴매 & 점에비 & 강 \\
\hline ‘02년 & 820 & 6,915 & $12 \%$ & \\
\hline ‘03년 & 1,217 & 6,781 & $18 \%$ & $+6 \%$ \\
\hline '04년 & 1,233 & 6,190 & $20 \%$ & $+2 \%$ \\
\hline \multicolumn{5}{|c|}{ 〈그림 4-3〉 국제선 항공권 판매실적 } \\
\hline 연 도 & 언타엉 & 전제 면미 & 정유니 & 622 \\
\hline '02년 & 170 & 14,891 & $1.1 \%$ & \\
\hline ‘03년 & 260 & 14,082 & $1.8 \%$ & $+0.7 \%$ \\
\hline '04년 & 450 & 16,404 & $2.7 \%$ & $+0.9 \%$ \\
\hline
\end{tabular}

〈그림 4-4〉 연령별 인터넷 회원 점유율

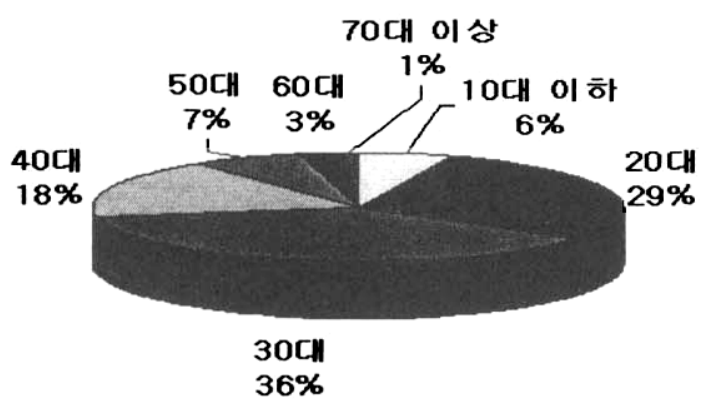

남성이 61\%(219만 명), 여성이 39\%(139만 명) 를 각각 점유하고 있다. 연령별로는 30 대 $(36 \%)$ 가 가장 많고 20 대 $(29 \%), 40$ 대 $(18 \%)$ 순서로 높은 점유비를 보이고 있다(〈그림 4-4〉 참고). 대한항공의 인터넷 회원은 매년 60 만 명 이상 증가하는 추세를 보이고 있으며, 1 일 기준으로 약 1,500 2,000명이 신규 가입을 하고 있다. 〈그림 4-5〉에서 알 수 있듯이 인터넷 회원 수 는 연평균 $25 \%$ 의 성장을 지속해 왔는데, 이는 연평균 $10 \%$ 의 증가율을 보이고 있는 스카이패
스 회원의 증가율과 비교해 볼 때 매우 높은 증가율이라고 할 수 있다. 또한 현재 홈 페이지 방문자 수는 120,000 명에 이르며, 하루 평균 $1,490,000$ 에 달하는 웹페이지가 방문되고 있다. 대한항공은 현재 2005년 말까지 회원 수 430 만 명을 목표로 회원 확보를 위해 다양한 마케팅 활동을 수행하고 있다. 
〈그림 4-5〉 인터넷 회원의 증가 추세

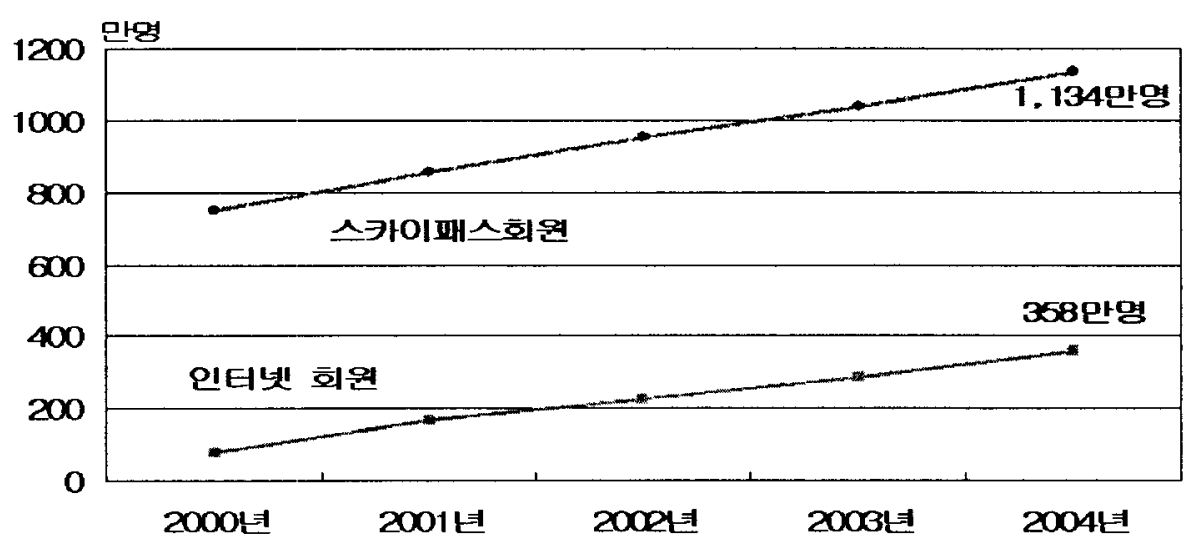

\section{3 비용의 감소}

항공 서비스업은 그 특성상 기내 서비스 이 외에도 티켓 판매와 관련하여 콜 센터 및 티켓 팅 카운터 등 노동력이 많이 필요한 노동집약 적 사업이다. 따라서 인터넷 마케팅을 통하여 고객들로 하여금 티켓 카운터를 이용하는 대신 에 인터넷 회원가입을 거쳐 온라인상에서 직접 티켓을 구매하고, 콜 센터에 문의하는 대신에 인터넷상의 고객지원 센터에 문의를 하게 함으 로써, 대한항공은 상당한 비용절감의 효과를 얻게 되었다. 보다 구체적으로 살펴보면, 대한 항공은 인터넷 마케팅 활동으로 예약, 발권 시 설 및 인력관리 비용, 판매 시설 및 인력 관련 비용, 직원 교육 관련 비용, 판매촉진 할동비 용, 대리점 관리 비용, 판매 수수료 비용, 고객 관리 비용 등의 다양한 부문에 있어서 비용을 절감할 수 있었다.

\section{1 시사점}

지금까지 대한항공의 사례를 연구하면서 몇 가지 시사점을 얻을 수 있었다.

첫째, 대한항공의 인터넷 마케팅 사례는 기존 의 직접 판매 채널의 한계를 극복하기 위해 새 로운 채널인 인터넷을 어떻게 전략적으로 활용할 수 있는 가를 잘 보여주고 있다. 대한항공은 인 터넷을 통한 직접 판매를 확대함으로써 수익 창 출 및 비용 절감 효과를 동시에 얻을 수 있었다.

둘째, 고객 특성 및 욕구를 최대한 반영하여 인터넷 상품을 기획하는 것이 중요하다. 과거 오프라인 채널을 통해 판매되어 온 항공권만을 온라인을 통해서 새롭게 판매하는 단순한 접근 방식에서 벗어나, 여러 할인항공권과 여행상품 등 다양한 신상품의 개발을 통해 오프라인 매 출의 온라인 매출로의 단순전환이 아닌 새로운 매출의 증대를 꾀하였다. 또한 인터넷 채널을 선호하는 고객의 특성을 잘 파악하여 그들이 
중시하는 편의성과 가격의 요인 차원에서 고객 을 세분화한 후, 세분시장 별로 각기 다른 포지 셔닝 전략을 수립함으로써 좋은 판매 성과를 거둘 수 있었다.

셋째, 온라인과 오프라인간의 마케팅 활동이 통합적으로 그리고 상호보완적으로 관리되어야 한다는 점이다. 예를 들어 커뮤니케이션 전략 측면에서 온라인 환경하에서의 커뮤니케이션 활동을 오프라인상 활동들과 일관성있게 그리 고 상호보완적으로 활용함으로써 효율성을 극 대화시킬 수 있을 것이다.

\section{2 결언}

1997년 6월부터 시작된 대한항공의 인터넷 마 케팅 활동은 지금까지 큰 성과를 거두었다. 그 러나 대한항공은 앞으로 풀어야할 다음과 같은 전략적 과제를 가지고 있다.

첫째, $\mathrm{E}-\mathrm{CRM}$ 시스템으로의 전환이다. 관계 마케팅은 '약속의 수행'을 통해 고객관계의 구 축, 유지, 강화 그리고 상거래의 관계를 유지해 가는 데 그 목적이 있다(Gronroos 1990). 웹 사 이트 발전단계 중 3 단계인 e-CRM의 실현을 위해서, 대한항공은 온라인 고객 데이터베이스 의 활용을 통해 일대일 마케팅의 수준으로 인 터넷 마케팅을 발전시켜야 할 것이다. 이를 위 해서는 고객별 구매기록 데이터를 전략적으로 활용할 수 있는 모형 또는 분석도구의 개발이 필요하다. 이를 통하여 고객별로 과거구매 패턴 을 분석함으로써 상품, 가격, 광고, 또는 판촉활 동을 각 고객별로 상이한 형태로 전개하는 것 이 가능하게 될 것이다. 예를 들어 신규 여행상 품의 경우 어떤 고객들에게 얼마의 가격으로
어떤 편익을 강조하여 접촉할 것인가에 대한 답을 얻을 수 있을 것이다. 이외에도 할인 항공 권의 가격결정의 경우, 현재에는 직관에 의존하 고 있는데 보다 정교한 분석모형을 활용하여 최적가격을 결정할 수도 있다. 이와 같은 분석 모형의 개발이 필요한 이유는 진정한 의미의 $\mathrm{E}-\mathrm{CRM}$ 시스템의 실현은 하드웨어나 데이터베 이스의 구축을 넘어, 수집된 정보를 일대일 마 케팅의 구현을 위해 어떻게 전략적으로 분석·활 용할 것인가에 결정적으로 달려있기 때문이다.

둘째, 온라인과 오프라인 활동의 보다 효율적 인 전략적 통합이다. 대한항공은 티켓 판매 중 여전히 대부분을 차지하고 있는 간접판매의 수 요를 어떻게 보다 빠른 시간 내에 직접 판매로 전환시킬 것인가를 고민하고 있다. 그러나 무별 하고 지나친 판촉활동을 통한 직접 판매로의 전 환유도는 오히려 전체 수익을 감소시키는 부정적 인 결과를 초래할 수 있으므로 온라인과 오프라 인 두 채널 간의 제살갉아먹기(cannibalization) 를 피하면서 전체 수익률의 크기를 증가시키는 방향으로 직접판매 전략이 수립되어야 할 것이 다. 커뮤니케이션 전략 등 기타 마케팅 믹스전 략 또한 온라인과 오프라인간 갈등을 최소화하 고 시너지효과를 창출할 수 있도록 수립되어야 할 것이다.

셋째, SKYPASS로 관리되는 대한항공의 마 일리지 회원을 인터넷 회원으로 전환시키는 것 이 중요하다. 현재 1,200 만 명의 마일리지 회원 중 400 만 명만이 인터넷 회원으로 가입되어 있 다. 일반적인 마일리지 회원은 고객이 필요시에 만 연락을 취하므로 항공사에서 적극적인 마케 팅 활동을 하기 어려운 단점이 있다. 이에 비해 마일리지 회원이 인터넷 회원으로 전환된다면 
고객에 대해 더 많은 정보를 얻을 수 있고 그 정보를 바탕으로 보다 차별화되고 맞춤화된 마 케팅 활동을 실행할 수 있게 될 것이다.

마지막으로 보다 효율적인 e-commerce환경 을 구축해야 한다. 이를 위해서 고객이 보다 사용하기 쉽도록 인터넷 환경을 지속적으로 개선하고, 고객의 요구에 대한 실시간 피드백 이 가능하도록 기술 및 인력 자원을 확충해야 할 것이다.

〈사례 접수일: 2005. 09. 29〉 〈게재 확정일: 2005. 09. 29〉

\section{참고문헌}

이두희(2003), 통합적 인터넷 마케팅, 서울, 박 영사.

Global Aerospace(2000), Trends in the Airline Industry, UK: London, July.

Gronroos, Christian(1990), "Relaitonship Approach to Marketing in Service Contexts: The Marketing and Organizational Behavior Interface," Journal of Business Research, 20, 3-11.

Strauss, Frost(1999), Marketing on the Internet: Principles of Online Marketing, UK: Englewood Cliffs, Prentice Hall, Inc. 


\title{
Korean Air: An Internet Marketing Case
}

\author{
Jae Il Kim* \\ Jin Gyo Kim** \\ Donghoon Kim***
}

\begin{abstract}
This paper presents Korean Air's internet marketing strategy. Its vision, missions, and implementation for internet marketing are discussed. The performance and impact of its internet marketing strategies is also examined.
\end{abstract}

Keywords: Internet Marketing, E-commerce, E-CRM

* Professor, College of Business Administration, Seoul National University

** Assistant Professor, College of Business Administration, Seoul National University

*** Professor, Yonsei School of Business 